\title{
Intestinal parasite infection exposes grouse to canine predators
}

\author{
Marja Isomursu ${ }^{1 *}$, Osmo Rätti ${ }^{2}$, Pekka Helle ${ }^{3}$, Tuula Hollmén ${ }^{4}$ \\ From Parasite infections of domestic animals in the Nordic countries - emerging threats and challenges. \\ The 22nd Symposium of the Nordic Committee for Veterinary Scientific Cooperation (NKVet) \\ Helsinki, Finland. 7-9 September 2008
}

\section{Background}

Sublethal parasite infections may cause mortality indirectly by exposing the host to predation. The best known example of this among birds is red grouse in which caecal nematode infection causes increased risk of predation and can even affect population dynamics [1]. Intestinal helminth parasites are common in forest grouse, capercaillie Tetrao urogallus, black grouse Tetrao tetrix and hazel grouse Bonasa bonasia [2], and these grouse are valuable prey for several species of predators. We evaluated the hypothesis that parasite infection makes the host more vulnerable to predation by comparing the intestinal parasite infection status of grouse hunted with a trained dog to that of grouse hunted without a dog. Hunting with a dog can be regarded as close simulation of natural predation because the dog presumably locates the prey by the same cues as wild canine predators.

\section{Material and methods}

We collected whole grouse intestines from hunters and received 623 samples of which the bird species, age class and sex were determined. All sample birds were shot with a shotgun during legal hunting season in September and October. Intestines were cut open and parasites visible to naked eye or stereomicroscope were extracted and identified. The associations between host sex, age, species, the month of sampling, the use of dog and the occurrence of intestinal helminths were studied using hierarchical loglinear modelling with backward elimination procedure $(\mathrm{P}=0.05)$ (SPSS programme ver. 11.5). Two different models were studied, one for cestodes (all three species pooled together) and one for nematodes.

\footnotetext{
${ }^{1}$ Finnish Food Safety Authority Evira, Research Department, Fish and Wildlife Health Research Unit, P.O.Box 517, FI-90101 Oulu, Finland

Full list of author information is available at the end of the article
}

\section{Results and conclusions}

Grouse were infected by four helminth species: a nematode Ascaridia compar and cestodes Skrjabinia cesticillus, Paroniella urogalli and Hymenolepis sp. Nematode infection was not connected to dog-assisted hunting. However, there was a significant interaction between cestode infection and the use of $\operatorname{dog}(\mathrm{P}<0.01)$. Cestodes were more common in grouse hunted with a dog (see Figure 1).

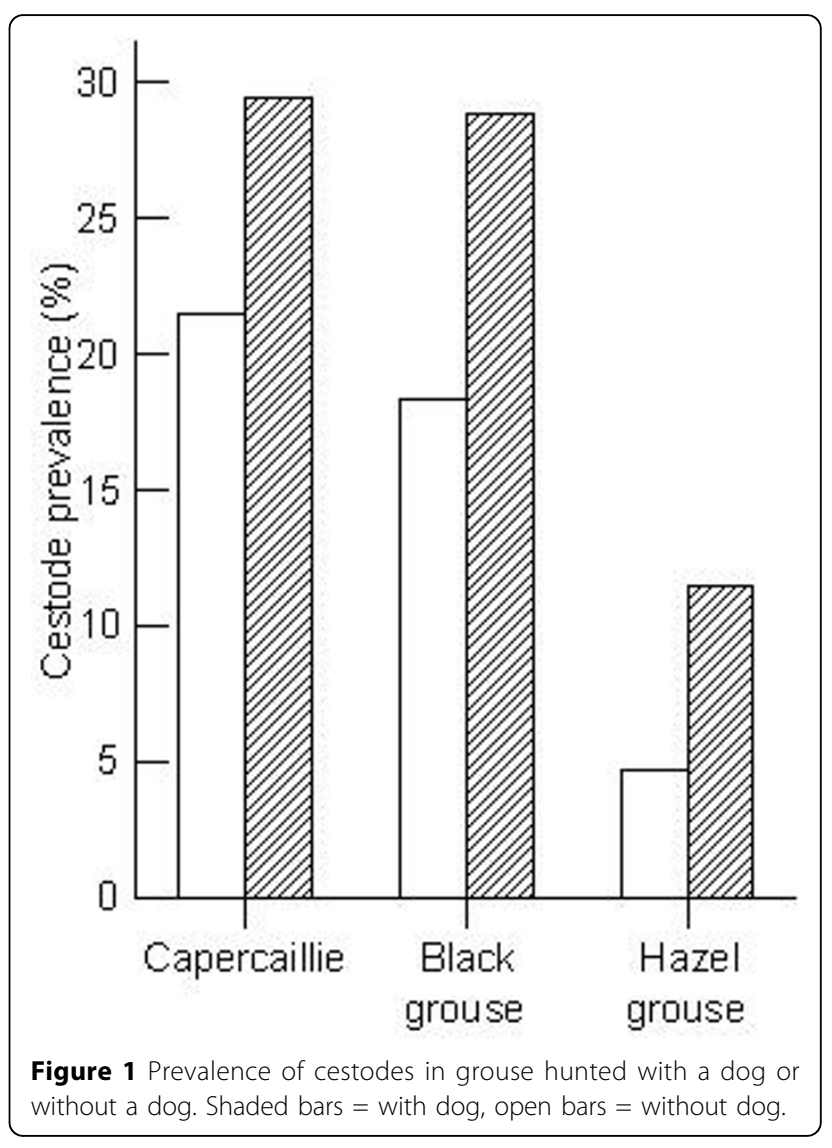


Cestodes were mostly parasites of juvenile grouse but even among juveniles only, cestodes were more prevalent in the dog-assisted hunting bag. The results suggest that mammalian predators prey more selectively on parasitized individuals and that intestinal parasites may contribute to the high mortality of juvenile grouse through increased predation.

This abstract is based on a recent paper published in Annales Zoologici Fennici by the same authors [3].

\section{Author details}

'Finnish Food Safety Authority Evira, Research Department, Fish and Wildlife Health Research Unit, P.O.Box 517, Fl-90101 Oulu, Finland. ${ }^{2}$ Arctic Centre, University of Lapland, P.O.Box 122, Fl-96101 Rovaniemi, Finland. ${ }^{3}$ Finnish Game and Fisheries Research Institute, Oulu Game and Fisheries Research, Tutkijantie 2 E, Fl-90570 Oulu, Finland. ${ }^{4}$ Alaska Sealife Center, 301 Railway Avenue, P.O. Box 1329, Seward, AK 99664, USA.

Published: 13 October 2010

\section{References}

1. Dobson A, Hudson P: The interaction between the parasites and predators of red grouse Lagopus lagopus scoticus. Ibis 1995, 137:S87-S96.

2. Isomursu $M$, Helle P, Rätti O: Intestinal helminths in Finnish grouse. Suomen Riista 2004, 50:90-100, (In Finnish with English summary).

3. Isomursu M, Rätti $\mathrm{O}$, Helle P, Hollmén T: Parasitized grouse are more vulnerable to predation as revealed by a dog-assisted hunting study. Ann Zool Fennici 2008.

\section{Submit your next manuscript to BioMed Central} and take full advantage of:

- Convenient online submission

- Thorough peer review

- No space constraints or color figure charges

- Immediate publication on acceptance

- Inclusion in PubMed, CAS, Scopus and Google Scholar

- Research which is freely available for redistribution

Submit your manuscript at www.biomedcentral.com/submit 